\title{
Clinical Progress and Pharmacology of Small Molecule Bromodomain Inhibitors
}

\author{
Natalie H. Theodoulou ${ }^{[a, b, 1]}$, Nicholas C. O. Tomkinson ${ }^{[b]}$, Rab K. \\ Prinjha $^{[a]}$ and Philip G. Humphreys ${ }^{[a]}$ \\ a Epinova Epigenetics Discovery Performance Unit, GlaxoSmithKline R\&D, Stevenage, \\ Hertfordshire, SG1 2NY, U.K. \\ b WestCHEM, Department of Pure and Applied Chemistry, Thomas Graham Building, \\ University of Strathclyde, 295 Cathedral Street, Glasgow, G1 1XL, U.K.
}

Corresponding author: Philip G. Humphreys (philip.g.humphreys@gsk.com)

\begin{abstract}
Bromodomains have emerged as an exciting target class for drug discovery over the past decade. Research has primarily focused on the bromodomain and extra terminal (BET) family of bromodomains, which has led to the development of multiple small molecule inhibitors and an increasing number of clinical assets. The excitement centred on the clinical potential of BET inhibition has stimulated intense interest in the broader family and the growing number of non-BET bromodomain chemical probes has facilitated phenotypic investigations, implicating these targets in a variety of disease pathways including cancer, inflammation, embryonic development and neurological disorders.
\end{abstract}

\section{Introduction}

As a result of the understanding that a failure to appropriately control gene expression may underlie most human diseases, epigenetics and the promise of epigenetic therapeutics has rapidly grown into one of the most promising and fertile areas of drug discovery. ${ }^{1}$ There are at least 56 human bromodomains and these reader modules selectively recognise acetyl lysine (KAc) residues present in both histone and non-histone proteins (Figure 1). Since the first disclosure in 2005 that a small molecule was capable of binding to a bromodomain, ${ }^{2}$ the number of reported inhibitors has expanded drastically, particularly in the past six years, with the disclosure of a large number of small molecule bromodomain chemical probes. The profound and broad pharmacology of bromodomain inhibition, especially that associated with the BET family of bromodomains (BRD2, BRD3, BRD4 and BRDT), has led to the progression of a number of small molecule assets into the clinic. Herein, we discuss the exciting progress of BET bromodomain inhibitors currently undergoing human clinical trials and the emerging pharmacology associated with the less mature field of chemical probes targeting bromodomains outside of the BET family.

\footnotetext{
${ }^{1}$ Present address: Flexible Discovery Unit, GlaxoSmithKline R\&D, Stevenage, Hertfordshire, SG1 2NY, U.K.
} 


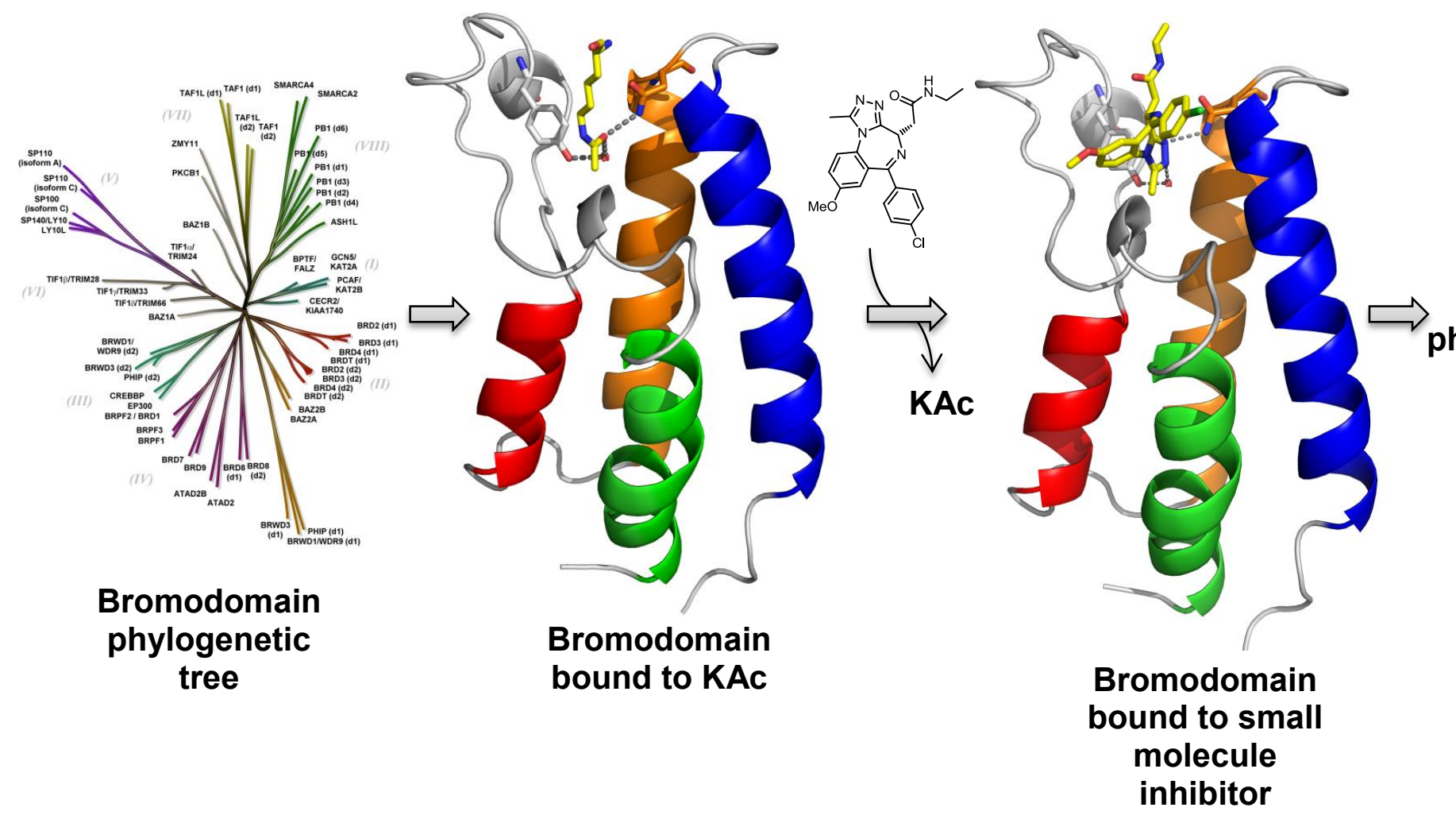

Figure 1: Small molecule bromodomain inhibitor binding to a bromodomain and displacing KAc from the binding site. This interaction typically leads to broad pharmacology and has been implicated in a variety of human disease.

\section{BET bromodomain inhibitors in clinical trials}

There has been significant interest in the BET family of bromodomains due to their potential as therapeutic targets for a number of diseases including cancer, inflammation and cardiovascular disease. The first inhibitors reported for the BET family of bromodomains were structurally related I-BET762 (1) $)^{3,4,5}$ and (+)-JQ1 (2) ${ }^{6}$ reported by GlaxoSmithKline (GSK) and the Structural Genomics Consortium (SGC) respectively (Figure 2).

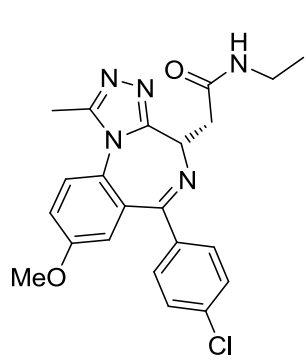

GSK525762/I-BET762 (1)

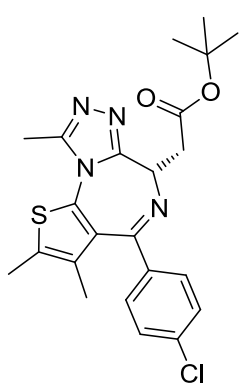

(+)-JQ1 (2)

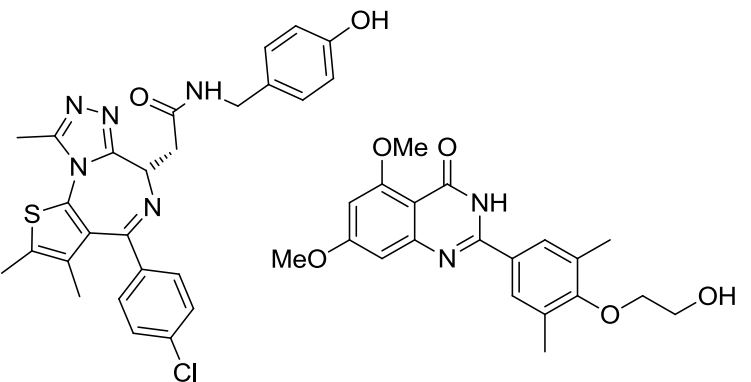

OTX015/MK-8628 (3)
RVX-208/ Apabetalone (4)

Figure 2: Chemical structures of BET bromodomain inhibitors I-BET762 (1), (+)-JQ1 (2), OTX015 (3) and RVX-208 (4). 
This disclosure and ready availability of high quality small molecules such as I-BET762 (1) and (+)-JQ1 (2) stimulated academic and industrial research in the field. The development of a wide number of BET bromodomain chemical probes including I-BET762 (1) and (+)-JQ1 (2) and their biological effects has been widely reported in a number of excellent reviews $7,8,9,10,11,12,13,14$ however, the constantly growing numbers of patents and BET inhibitors in reported pre-clinical and clinical development highlights the substantial interest and investment in the potential of BET bromodomain inhibition for improving human health. As of January 2016, there are 14 small molecule BET inhibitors registered as undergoing clinical trials in a total of 20 studies (Table 1 ).

Table 1: BET bromodomain inhibitors registered as undergoing human clinical trials

\begin{tabular}{|c|c|c|c|c|}
\hline Compound & Sponsor & Indication(s) & Status & NCT number \\
\hline ABBV-075 & AbbVie & $\begin{array}{l}\text { Advanced Cancer, Breast Cancer, } \\
\text { NSCLC, AML, Multiple Myeloma }\end{array}$ & Phase I (recruiting) & NCT02391480 \\
\hline BAY 1238097 & Bayer & Neoplasms & $\begin{array}{l}\text { Phase I (active, not } \\
\text { recruiting) }\end{array}$ & NCT02369029 \\
\hline BI 894999 & $\begin{array}{l}\text { Boehringer } \\
\text { Ingelheim }\end{array}$ & Advanced Solid Tumours & Phase I (recruiting) & NCT02516553 \\
\hline BMS-986158 & $\begin{array}{l}\text { Bristol-Myers } \\
\text { Squibb }\end{array}$ & Multiple Indications Cancer & $\begin{array}{l}\text { Phase } 1 / 1 \text { la } \\
\text { (recruiting) }\end{array}$ & NCT02419417 \\
\hline CPI-0610 & $\begin{array}{c}\text { Constellation } \\
\text { Pharmaceuticals }\end{array}$ & Lymphoma & Phase I (recruiting) & NCT01949883 \\
\hline “ & “ & Multiple Myeloma & Phase I (recruiting) & NCT02157636 \\
\hline “ & “ & AML MDS, MDS/MPN & Phase I (recruiting) & NCT02158858 \\
\hline FT-1101 & $\begin{array}{c}\text { Forma } \\
\text { Therapeutics }\end{array}$ & AML, MDS & Phase I (recruiting) & NCT02543879 \\
\hline INCB054329 & $\begin{array}{l}\text { Incyte } \\
\text { Corporation }\end{array}$ & Advanced Cancer & $\begin{array}{l}\text { Phase I/II } \\
\text { (recruiting) }\end{array}$ & NCT02431260 \\
\hline $\begin{array}{l}\text { GSK525762/ } \\
\text { I-BET762 (1) }\end{array}$ & GlaxoSmithKline & NMC; Other Cancers & Phase I (recruiting) & NCT01587703 \\
\hline “ & " & Hematologic Malignancies & Phase I (recruiting) & NCT01943851 \\
\hline GSK2820151 & “ & Solid Tumors & $\begin{array}{l}\text { Phase I (not yet } \\
\text { recruiting) }\end{array}$ & NCT02630251 \\
\hline GS-5829 & Gilead Sciences & CRPC & Phase I (recruiting) & NCT02607228 \\
\hline $\begin{array}{l}\text { N-Methyl- } \\
\text { Pyrrolidone }\end{array}$ & $\begin{array}{l}\text { Peter MacCallum } \\
\text { Cancer Centre, } \\
\text { Australia }\end{array}$ & Multiple Myeloma & $\begin{array}{l}\text { Phase I (not yet } \\
\text { recruiting) }\end{array}$ & NCT02468687 \\
\hline $\begin{array}{c}\text { OTX015/ } \\
\text { MK-8628 (3) }\end{array}$ & $\begin{array}{l}\text { OncoEthix GmbH } \\
\text { (now Merck) }\end{array}$ & AML, hematologic malignancies & Phase I (recruiting) & NCT01713582 \\
\hline “ & " & $\begin{array}{c}\text { NMC, TNBC; NSCLC, CRPC; } \\
\text { Pancreatic Ductal Adenocarcinoma }\end{array}$ & Phase lb (recruiting) & NCT02259114 \\
\hline “ & “ & Glioblastoma Multiforme & $\begin{array}{l}\text { Phase lla } \\
\text { (terminated) }\end{array}$ & NCT02296476 \\
\hline
\end{tabular}




$\begin{array}{cc} & \text { Tensha } \\ \text { TEN-010 } & \begin{array}{l}\text { Therapeutics } \\ \text { (now Roche) }\end{array}\end{array}$

AML, MDS

Solid Tumors
Phase I (recruiting)

NCT02308761

“

“

Phase I (recruiting)

NCT01987362

Structures, where known, are shown in Figure 2. Abbreviations: AML, Acute Myeloid Leukemia; CAD, Coronary Heart Disease; CRPC, Castrate Resistant Prostate Cancer; MDS/MPN, Myelodysplastic/Myeloproliferative Neoplasms; NMC, Nut-Midline Carcinoma; NSCLC, Non-Small Cell Lung Cancer; TNBC, Triple Negative Breast Cancer; T2DM, Type 2 Diabetes mellitus.

The vast majority of BET inhibitors undergoing human clinical trials are initially being investigated in an oncology setting (Table 1). Due to the ongoing nature of most of these clinical studies, there are limited data available. However, OncoEthix (acquired by Merck in 2014) have completed a Phase I trial in patients with acute myeloid leukemia (AML) and other haematological malignancies with OTX015/MK-8628 $(3) \cdot{ }^{15,16,17,18}$ This orally available molecule is well tolerated up to $80 \mathrm{mg}$ once a day (QD) with diarrhoea/fatigue and reversible thrombocytopenia observed as the dose limiting toxicity in patients with AML and other haematological malignancies respectively. Trough plasma concentrations at $80 \mathrm{mg}$ QD reached the $\mathrm{GI}_{50}$ concentration of $500 \mathrm{nM}$ for sensitive tumor cell lines in vitro and clinically meaningful activity was seen in AML and lymphoma patients. These encouraging responses have led to progression of OTX015/MK-8628 (3) into additional clinical trials.

Constellation have reported a preliminary analysis of an ongoing Phase I trial with CPI-0610 in lymphoma patients. ${ }^{19}$ The compound is well tolerated and similar to that seen with OTX015/MK-8628 (3), the principal toxicity was reversible thrombocytopenia. Expression of the BET target gene chemokine C-C motif receptor 1 (CCR1) was suppressed at $170 \mathrm{mg}$ and $230 \mathrm{mg} \mathrm{QD}$, associated with plasma CPI-0610 concentrations $\geq 3 \mu \mathrm{M}$ and antilymphoma activity has been observed in patients with 80-230 mg QD doses.

Tensha Therapeutics (acquired by Roche in 2016) have reported clinical efficacy and tolerability in three NUT-midline carcinoma (NMC) patients with subcutaneous QD dosing of TEN-010 for three weeks in a four-week cycle. ${ }^{20}$ The compound and dosing regimen was tolerated with reversible irritation of the injection site, increases of bilirubin and anorexia reported. This observed efficacy in three NMC patients with TEN-010 provides hope that $\mathrm{BET}$ inhibition may provide a treatment for this rare and clinically aggressive cancer.

There are ten other companies progressing BET bromodomain inhibitors in oncology clinical trials for both solid and haematological malignancies (Table 1). However, of note is the Peter MacCallum Cancer Centre in Australia who have entered $\mathrm{N}$-methyl-pyrrolidone (NMP) into human trials for cancer. It has been reported that this common laboratory solvent can act as a low affinity broad spectrum bromodomain inhibitor with binding demonstrated to multiple bromodomains including BET. In a mouse model of myeloma, treatment with NMP demonstrated antineoplastic and immunomodulatory activity consistent with BET inhibition. ${ }^{21}$

Outside of oncology, the most advanced bromodomain inhibitor undergoing clinical trials is RVX-208 (4), also known as Apabetalone. This compound, identified via an ApoA1 upregulation phenotypic screen, ${ }^{22}$ is selective for the second BET bromodomain ${ }^{23}$ and has completed Phase II clinical trials for a number of cardiovascular diseases including coronary artery disease, type II diabetes mellitus and atherosclerosis. ${ }^{24} \mathrm{~A}$ post-hoc analysis from two pooled Phase II trials (NCT01423188 and NCT01067820) demonstrated that patients with cardiovascular disease had a statistically significant decrease in major adverse 
cardiovascular events (MACE) when given RVX-208 (4). As such, this compound has recently entered a Phase III trial titled 'BETonMACE' aiming to reduce MACE in high-risk type II diabetes mellitus patients with coronary artery disease and low high-density lipoprotein. ${ }^{25}$

\section{Non-BET bromodomain chemical probes}

High quality chemical probes are an important tool for preclinical target validation ${ }^{26,27}$ and there have been many important contributions from both academic and industrial laboratories in the development and biological testing of non-BET bromodomain chemical probes. $8^{-14,28}$ Due to the profound and wide-ranging biology associated with BET family bromodomain inhibition, BET selectivity is an essential criteria during generation of a chemical probe and in this review we focus on the recent developments of those non-BET bromodomain chemical probes with a reported structure, selectivity over BET and demonstrated pharmacology (Figure 3).

(a)

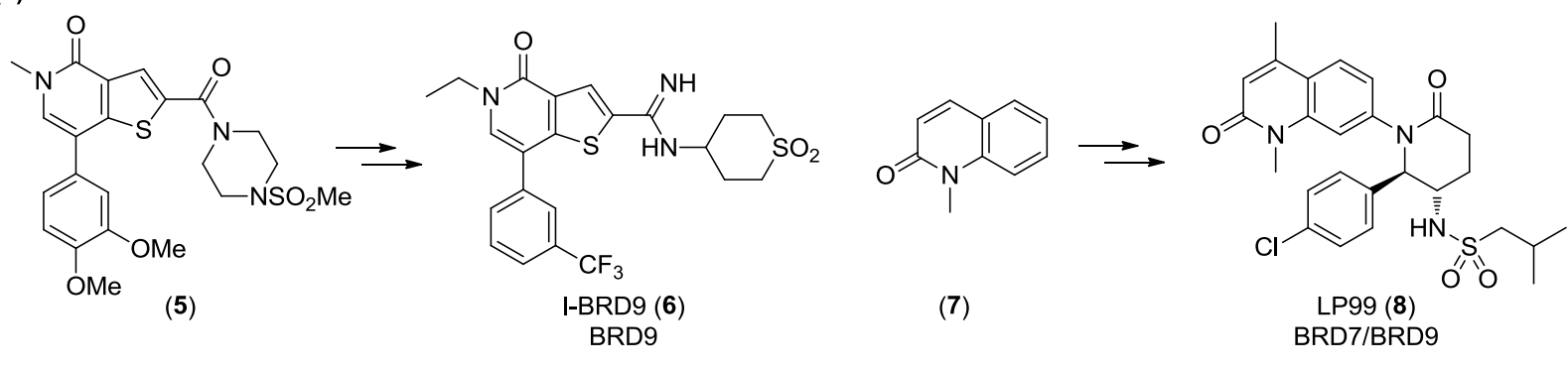

(b)<smiles>Cc1noc(C)c1-c1ccc2[nH]cnc2c1</smiles>

(9)

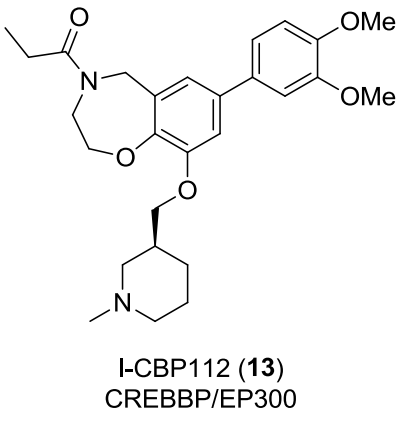

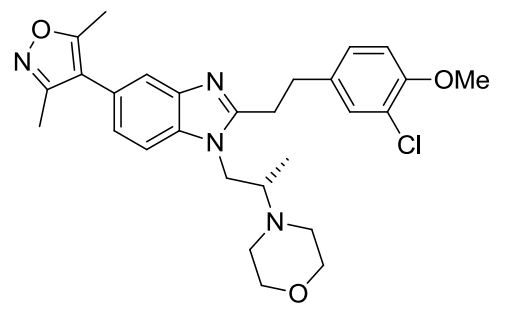

SGC-CBP30 (10) CREBBP/EP300

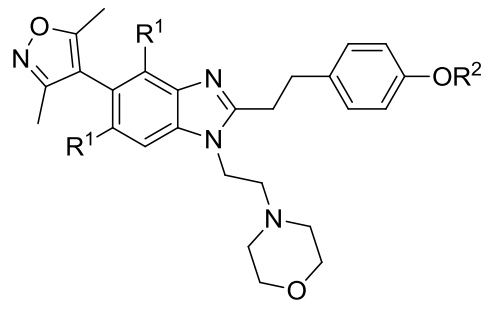

$\mathrm{R}^{1}=\mathrm{H}, \mathrm{R}^{2}=n-\mathrm{Pr}: \mathrm{PF}-\mathrm{CBP} 1$ (11) CREBBP/EP300

$\mathrm{R}^{1}=\mathrm{R}^{2}=$ Me: ISOX-INACT (12) negative control (c)

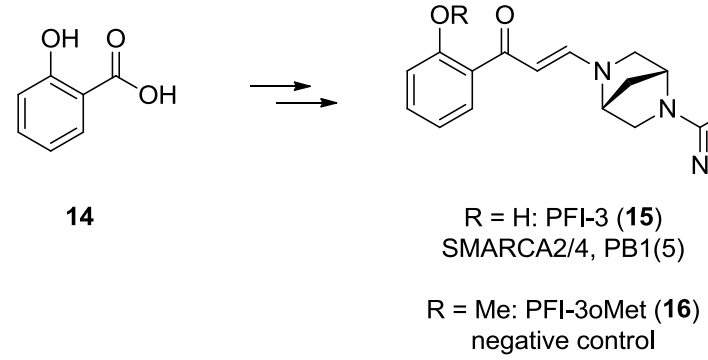

Figure 3: Chemical structures of selected non-BET bromodomain chemical probes targeting (a) BRD9 and BRD7/9I (b) CREBBP/EP300 and (c) SMARCA2/4 and PB1(5). 


\section{Initial start points for the optimisation of these compounds are included where known.}

\section{BRD7 and BRD9}

Although the precise biological role of bromodomain containing protein 9 (BRD9) is currently unknown, it has been reported as a component of the switch/sucrose non-fermentable (SWI/SNF) brahma-related gene 1-associated factor (BAF) complex, which plays a key role in chromatin remodelling and transcription control. ${ }^{29}$ Highly homologous bromodomain containing protein 7 (BRD7) is a component of the SWI/SNF polybromo-associated BAF (PBAF) complex and has been proposed as a tumor suppressor ${ }^{30}$ Within the last year, there have been several publications focussing on BRD9 and dual BRD7/9 chemical probe development. ${ }^{31,32,33}$

GSK and the University of Strathclyde identified I-BRD9 (6) as the first selective chemical probe for BRD9 (Figure 3a). ${ }^{34}$ Using structure-based design, I-BRD9 (6) was developed from tertiary amide 5. Critical to the success of the programme was the identification of the BET selective amidine moiety and the $N$-ethyl group which provided selectivity over the broader bromodomain families. I-BRD9 (6) shows excellent activity (BRD9 $\mathrm{K}_{\mathrm{d}}: 1.9 \mathrm{nM}$ ) and is $\geq 70$ fold selective over every other bromodomain tested, including the highly homologous BRD7. This remarkable selectivity profile with activity for a single bromodomain allowed investigation of the pharmacology of BRD9 bromodomain binding. In a cell line model of human acute myeloid leukaemia, Kasumi-1 cells were treated with I-BRD9 (6) and BET bromodomain chemical probe I-BET151. ${ }^{35}$ Transcriptomic analysis demonstrated that although there was some overlap, the majority of genes were selectively regulated by IBRD9 (6), including CLEC1, DUSP6, FES, and SAMSN1, which have been implicated in cancer and immunology pathways.

In parallel, research by the University of Oxford and the SGC, led to the discovery of LP99 (8) as the first reported dual BRD7/9 chemical probe (Figure 3a). ${ }^{36}$ Using fragment quinolone 7 as a start point, LP99 (8) was developed using structure-based design to guide introduction of a 4-methyl group to occupy a shallow hydrophobic pocket and a complex lactam to the quinolone 7-position to obtain the desired potency and selectivity. LP99 (8) displays excellent BRD9 ( $\left.\mathrm{K}_{d}: 99 \mathrm{nM}\right)$ and BRD7 ( $\mathrm{K}_{\mathrm{d}}$ : $\left.909 \mathrm{nM}\right)$ activities, with good selectivity across the broader bromodomain families. Importantly, no activity was seen against the BET family which allows straightforward use of LP99 (8) in phenotypic investigations of BRD7/9 inhibition. Studies demonstrated that LP99 (8) inhibited the secretion of proinflammatory cytokine interleukin-6 (IL-6) in human THP-1 monocytes when stimulated with lipopolysaccharide (LPS). The inhibition of the expression of this clinically relevant cytokine implicates BRD7/9 as a potential target for the treatment of rheumatoid arthritis. ${ }^{37}$

Further confidence in the potential of BRD7/9 bromodomain inhibitors for the treatment of disease comes from a patent from Genentech and Constellation Pharmaceuticals. ${ }^{38}$ These companies disclosed data that BRD7/9 inhibitors (structures not shown in patent) play an important role in the regulation of type 2 helper T cells (Th2) cytokine expression. In particular, these compounds were found to inhibit the production of IL-4, IL-5 and IL-13 in human Th2 cells, cytokines implicated in a variety of inflammatory and respiratory disorders.

\section{CREBBP and EP300}


Beyond the BET family, transcriptional co-activator cAMP response element binding protein (CREB) binding protein (CREBBP) and the evolutionary conserved adenoviral E1A binding protein (EP300) have received significant attention due to reported roles in cancer, inflammation and embryonic development. ${ }^{39,40,41}$ Together with important contributions from multiple academic laboratories, ${ }^{42,43,44,45}$ several BET selective chemical probes have provided an indication of the role of the CREBBP and EP300 bromodomains in human disease (Figure 3b).

SGC-CBP30 (10) was developed through a collaboration between the SGC and the University of Oxford starting from unselective fragment 9. ${ }^{46,47}$ SGC-CBP30 (10) is a potent binder of CREBBP and EP300 ( $\mathrm{K}_{\mathrm{d}}: 21$ and $35 \mathrm{nM}$ respectively) and importantly is 40 fold selective over BRD4. SGC-CBP30 (10) has been shown to reduce immune cell production of Th17 and other pro-inflammatory cytokines in cells derived from ankylosing spondylitis and psoriatic arthritis patients. Profiling SGC-CBP30 (10) at 1.1 or $0.37 \mu \mathrm{M}$ in a BioMAP panel of primary human cell types also revealed distinct immunomodulatory effects, whereas at higher concentrations the profiles overlapped with that of BET inhibitor (+)-JQ-1 (2).

Structurally related PF-CBP1 (11) was reported by researchers at Pfizer as a dual chemical probe for CREBBP and EP300. ${ }^{48}$ Although less potent than SGC-CBP30 (10), PF-CBP1 (11) is more selective with CREBBP $K_{d}: 190 \mathrm{nM}$ and $>105$ fold selectivity against BRD4. Moving from an aryl methoxy group to an aryl propoxy group was critical in reducing BRD4 potency while retaining CREBBP activity for this compound. Phenotypic studies showed that PFCBP1 (11) moderately reduced levels of IL-6, IL-1 $\beta$ and interferon- $\beta$ in an LPS stimulated mouse macrophage cell line, whereas structurally related negative control compound ISOXINACT (12) did not. Further supporting the role of CREBBP/EP300 in inflammation, the gene expression signature of primary macrophages treated with PF-CBP1 (11) showed specific modulation of inflammatory genes that was differentiated to that seen with BET inhibitor I-BET-762 (1). In addition, profiling in rat neurons revealed that PF-CBP1 (11) downregulated regulator of G-protein signalling 4 (RGS4), a target implicated in Parkinson's disease.

A collaboration between the SGC and GSK provided structurally distinct I-CBP112 (13) as a dual chemical probe for CREBBP and EP300. ${ }^{49}$ Although details of the development have not yet been disclosed, I-CBP112 (13) is active against CREBBP $\left(K_{d}: 151 \mathrm{nM}\right)$ and EP300 $\left(\mathrm{K}_{\mathrm{d}}\right.$ : $\left.625 \mathrm{nM}\right)$, with selectivity across the bromodomain family and 37 fold selectivity over BRD4. Biological studies with I-CBP112 (13) showed substantially impaired colony formation and induced cellular differentiation in human and mouse leukemic cell lines. The leukaemia-initiating potential of AML cells was also reduced both in vitro and in vivo.

As well as the BRD7/9 patents previously discussed, Genentech and Constellation Pharmaceuticals have also patented tetrahydroquinoxaline compounds as inhibitors of CREBBP and EP300. ${ }^{50}$ These compounds are disclosed for use in cancer immunotherapy due to their involvement in the regulation of regulatory $T$ cell function.

\section{SMARCA2/4 and PB1(5)}

Like BRD9, SWI/SNF-related, matrix-associated, actin-dependent regulator of chromatin, subfamily A, member 2 (SMARCA2) and related SMARCA4 have been reported as components of the mammalian chromatin remodelling SWI/SNF complexes. Loss of function of SMARCA4 and components of SWI/SNF has also been linked to cancer development and 
proposed as targets for treatment. ${ }^{51,52}$ Pfizer and the SGC disclosed PFI-3 (15) as a chemical probe for SMARCA2/4 and polybromo-1, bromodomain-5 [PB1(5)] with selectivity over the BET family (Figure 3c). ${ }^{53}$ Developed from salicylic acid (14), PFI-3 (15) demonstrates a highly unusual bromodomain binding mode which displaced four water molecules at the binding site which are highly conserved across a large number of bromodomain crystal structures. The bridged piperazine group not only provides shape complementarity to the bromodomain, positioning the pyridine ring within a hydrophobic pocket, it is also important to sterically protect the enamine from hydrolysis. Exposure of embryonic stem cells to PFI-3 (15) significantly altered gene expression programs that are important for stem cell differentiation, whereas negative control PFI-3oMet (16) did not. In addition, PFI-3 (15) induced enhanced differentiation of trophoblast stem cells, implicating the SMARCA2/4 and PB1(5) bromodomains in stem cell maintenance and differentiation. Further demonstrating the importance and utility of high quality chemical probes, PFI-3 (15) has also been used to invalidate the bromodomain as a target in SWI/SNF-mutant cancers. ${ }^{54}$

\section{Future perspectives}

The profound pharmacology of BET bromodomain inhibition has led to the instigation of multiple human clinical trials with small molecule BET bromodomain inhibitors. The progress of these assets is highly encouraging, with clinical efficacy being reported in multiple trials. However, as these mainly early phase trials are still ongoing, the true potential of BET bromodomain inhibitors for treating human disease will be unveiled over the coming years.

Due to the BET pharmacology that could prove so important in treating human diseases, obtaining excellent selectivity over this family is critical for the elucidation of non-BET bromodomain pharmacology with chemical probes. To date, the studies conducted with the non-BET bromodomain chemical probes discussed have implicated these proteins in cancer, inflammation, embryonic development and neurological disorders. Furthermore, the patenting of compounds which inhibit some of these proteins highlights the investment in this area and the potential for new and innovative medicines for the treatment of human disease. However, the bromodomains discussed represent a fraction of the phylogenetic tree and there is still a large amount of work to understand the pharmacology of all of them. During the preparation of this manuscript, one aspect that particularly stood out is the collaborative nature of the vast majority of the disclosures around non-BET bromodomain chemical probes, perhaps indicating that such collaborations are an excellent method to achieve this goal.

\section{Acknowledgements}

N.H.T. is grateful to GlaxoSmithKline R\&D, Stevenage for Ph.D. studentship funding.

\section{References and recommended reading}

Papers of particular interest, published within the period of review, have been highlighted as:

- of special interest

$\bullet \bullet$ of outstanding interest 
1. Arrowsmith $\mathrm{CH}$, Bountra $\mathrm{C}$, Fish PV, Lee K, Schapira M: Epigenetic protein families: a new frontier for drug discovery. Nat. Rev. Drug Disc. 2012, 11: 384-400.

2. Zeng L, Li J, Muller M, Yan S, Mujtaba S, Pan C, Wang Z, Zhou MM: Selective small molecules blocking HIV-1 tat and coactivator PCAF association. J. Am. Chem. Soc. 2005, 127: 2376-2377.

3. Nicodeme E, Jeffrey KL, Schaefer U, Beinke S, Dewell S, Chung CW, Chandwani R, Marazzi I, Wilson P, Coste H, White J, Kirilovsky J, Rice CM, Lora JM, Prinjha RK, Lee K, Tarakovsky AA: Suppression of inflammation by a synthetic histone mimic. Nature 2010, 468: 1119-1123.

- Together with reference 6 , the first disclosure that a small molecule was capable of binding to BET bromodomains and the profound pharmacology that results.

4. Mirguet O, Gosmini R, Toum J, Clement CA, Barnathan M, Brusq JM, Mordaunt JE, Grimes RM, Crowe M, Pineau O, Ajakane M, Daugan A, Jeffrey P, Cutler L, Haynes AC, Smithers NN, Chung CW, Bamborough P, Uings IJ, Lewis A, Witherington J, Parr N, Prinjha RK, Nicodeme E: Discovery of epigenetic regulator I-BET762: lead optimization to afford a clinical candidate inhibitor of the BET bromodomains. J. Med. Chem. 2013, 56: 7501-7515.

5. Chung CW, Coste H, White JH, Mirguet O, Wilde J, Gosmini RL, Delves C, Magny SM, Woodward R, Hughes SA, Boursier EV, Flynn H, Bouillot AM, Bamborough P, Brusq JMG, Gellibert FJ, Jones EJ, Riou AM, Homes P, Martin SL, Uings IJ, Toum J, Clement CA, Boullay AB, Grimley RL, Blandel FM, Prinjha RK, Lee K, Kirilovsky J, Nicodeme E: Discovery and characterisation of small molecule inhibitors of the BET family bromodomains. J. Med. Chem. 2011, 54: 3827-3838.

6. Filippalopoulos P, Qi J, Picaud S, Shen Y, Smith WB, Fedorov O, Morse EM, Keates T, Hickman TT, Felletar I, Philpott M, Munro S, McKeown MR, Wang Y, Christie AL, West N, Cameron MJ, Schwartz B, Heightman TD, La Thangue N, French CA, Wiest O, Kung AL, Knapp S, Bradner JE: Selective inhibition of BET bromodomains. Nature 2010, 468: 1067-1073.

- Together with reference 3, the first disclosure that a small molecule was capable of binding to BET bromodomains and the profound pharmacology that results.

7. Garnier JM, Sharp PP, Burns CJ: BET bromodomain inhibitors: a patent review. Expert Opin. Ther. Patents 2014, 24: 185-199.

- In depth review of the patent literature containing a large number of BET bromodomain inhibitors that have not been previously disclosed in journal articles 
8. Gallenkamp D, Gelato KA, Haendler B, Weinman $\mathrm{H}$ : Bromodomains and their pharmacological inhibitors. ChemMedChem 2014, 9: 438-464.

9. Jennings LE, Measures AR, Wilson BG, Conway SJ: Phenotypic screening and fragment-based approaches to the discovery of small-molecule bromodomain ligands. Future Med. Chem. 2014, 6: 179-204.

10. Bamborough $\mathrm{P}$, Chung $\mathrm{CW}$ : Fragments in bromodomain drug discovery. MedChemComm 2015, 6: 1587-1604.

11. Brand M, Measures AR, Wilson BG, Cortopassi WA, Alexander R, Höss M, Hewings DS, Rooney TPC, Paton R, Conway SJ: Small molecule inhibitors of bromodomain-acetyllysine interactions. ACS Chem. Biol. 2015, 10: 22-39.

12. Smith SG, Zhou MM: The Bromodomain: A New Target in Emerging Epigenetic Medicine. ACS Chem. Biol. 2015, DOI: 10.1021/acschembio.5b00831.

13. Ferri E, Petosa C, McKenna CE: Bromodomains: Structure, function and pharmacology of inhibition. Biochem. Pharmacol. 2015, doi:10.1016/j.bcp.2015.12.005.

14. Romero FA, Taylor AM, Crawford TD, Tsui V, Côté A, Magnuson S: Disrupting acetyllysine recognition: Progress in the development of bromodomain inhibitors. J. Med. Chem. 2015, DOI: 10.1021/acs.jmedchem.5b01514.

15. Herait PE, Berthon C, Thieblemont C, Raffoux E, Magarotoo V, Stathis A, Thomas X, Leleu X, Gomez-Roca C, Odore E, Roumier C, Bourdel F, Quesnel B, Zucca E, Michallet M, Recher C, Cvitkovic E, Rezai K, Preudhomme C, Facon T, Palumbo A, Dombret H: BETbromodomain inhibitor OTX015 shows clinically meaningful activity at nontoxic doses: interim results of an ongoing phase I trial in hematologic malignancies. Cancer Res. 2014, 74: CT231.

- First report of efficacy in humans of a BET inhibitor in an oncology clinical trial.

16. Dombret H, Preudhomme C, Berthon C, Raffoux E, Thomas X, Vey N, Gomez-Roca C, Ethell M, Yee K, Bourdel F, Herait P, Michallet M, Recher C, Roumier C, Quesnel B: A phase 1 study of the BET-bromodomain inhibitor OTX015 in patients with advanced acute leukemia. 56th American Society of Hematology Annual Meeting and Exposition, Sanfrancisco, CA, December 6-9, 2014, 117, Oral abstract.

17. Herait $P$, Dombret $H$, Thieblemont $C$, Facon $T$, Stathis $A$, Cunningham $D$, Palumbo A, Vey N, Michallet M, Recher C, Rezai K, Preudhomme C: BET-bromodomain (BRD) 
inhibitor OTX015: Final results of the dose-finding part of a phase I study in hematologic malignancies. Ann. Oncol. 2015, 26: ii10-ii11.

18. Odore E, Lokiec F, Cvitkovic E, Bekradda M, Herait P, Bourdel F, Kahatt C, Raffoux E, Stathis A, Thieblemont C, Quesnel B, Cunnigham D, Riveiro ME, Rezaï: Phase I population pharmacokinetic assessment of the oral bromodomain inhibitor OTX015 in patients with haematologic malignancies. Clin. Pharmacokinet. 2015, DOI: 10.1007/s40262-0150327-6.

19. Abramson JS, Blum KA, Flinn IW, Gutierrez M, Goy A, Maris M, Cooper M, O'Mera M, Borger D, Mertz J, Sims RJ, Jeffrey S, Younes A: BET inhibitor CPI-0610 is well tolerated and induces responses in diffuse large B-cell lymphoma and follicular lymphoma: preliminary analysis of an ongoing phase 1 Study. American Society of Hematology 57th Annual Meeting \& Exposition, Orlando, FL, December 5-8, 2015, 1491 abstract.

20. Shapiro GI, Dowlati A, LoRusso PM, Eder JP, Anderson A, Do KT, Kagey MH, Sirard C, Bradner JE, Landau SB: Clinically efficacy of the BET bromodomain inhibitor TEN-010 in an open-label substudy with patients with documented NUT-midline carcinoma (NMC). American Association for Cancer Research-National Cancer Institute-European Organsiation for Research and Treatment of Cancer International Conference on Molecular Targets and Cancer Therapeutics, Boston, MA, November 5-9, 2015, A49, Presentation Abstract.

21. Shortt J, Hsu AK, Martin BP, Doggett K, Matthews GM, Doyle MA, Ellul J, Jockel TE, Andrews DM, Hogg SJ, Reitsma A, Faulkner D, Bergsagel PL, Chesi M, Heath JK, Denny WA, Thompson PE, Neeson PJ, Ritchie DS, McArthur GA, Johnstone RW: The drug vehicle and solvent $\mathrm{N}$-methylpyrrolidone is an immunomodulator and antimyeloma compound. Cell Reports 2014, 7: 1009-101.

22. Picaud S, Wells C,Felletar I, Brotherton D, Martin S, Savitsky P, Diez-Dacal B, Philpott M, Bountra C, Lingard H, Fedorov O, Müller S, Brennan PE, Knapp S, Filippakopoulos P: RVX-208, an inhibitor of BET transcriptional regulators with selectivity for the second bromodomain. Proc. Natl. Acad. Sci. U.S.A. 2013, 110: 19754-19759.

23. McLure KG, Gesner EM, Tsujikawa L, Kharenko OA, Attwell S, Campeau E, Wasiak S, Stein A, White A, Fontano E, Suto RK, Wong NC, Wagner GS, Hansen HC, Young PR: RVX-208, an Inducer of ApoA-I in Humans, Is a BET Bromodomain Antagonist. PLoS. One. 2013, 8: e83190.

24 . Apabetalone/RVX-208 clinical development: Resverlogix: Calgary, http://www.resverlogix.com/programs/rvx-208-clinical-development/\#.VpPEj79kfOw (accessed Janurary 8th 2016).

25. Resverlogix commences dosing in phase 3 clinical trial BETonMACE: Resverlogix: Calgary, November 11, http://www.resverlogix.com/media/press-release.html?id=534\#.VoIpr9kfOw2015 (accessed January 8th 2016). 
26. Bunnage ME, Piatnitski Chekler EL, Jones LH: Target validation using chemical probes. Nat. Chem. Biol. 2013, 9: 195-199.

-• Excellent overview of the key criteria in delivering a high quality chemical probe suitable for target validation.

27. Sweis RF: Target (in)validation: a critical, sometimes unheralded, role of modern medicinal chemistry. ACS Md. Chem. Lett. 2015, 6: 618-621.

28. Theodoulou NH, Tomkinson NCO, Prinjha RK, Humphreys PG: Progress in the development of non-BET bromodomain chemical probes. ChemMedChem. 2016, DOI: 10.1002/cmdc.201500540.

29. Hohmann AF, Vakoc CR: A rationale to target the SWI/SNF complex for cancer therapy. Trends Genet. 2014, 30: 356-363.

30. Drost J, Mantovani F, Tocco F, Elkon R, Comel A, Holstege H, Kerkhoven R, Jonkers J, Voorhoeve PM, Agami R, Del Sal G: BRD7 is a candidate tumour suppressor gene required for p53 function. Nat. Cell Biol. 2010, 58: 380-389.

31. Guetzoyan L, Ingham RJ, Nikbin N, Rossignol J, Wolling M, Baumert M, Burgess-Brown NA, Strain-Damerell CM, Shrestha L, Brennan PE, Fedorov O, Knapp S, Ley SV: Machineassisted synthesis of modulators of the histone reader BRD9 using flow methods of chemistry and frontal affinity chromatography. MedChemComm 2014, 5: 540-546.

32. Picaud S, Strocchia M, Terracciano S, Lauro G, Mendez J, Daniels DL, Riccio R, Bifulco G, Bruno I, Fillipakopoulos P: 9H-Purine scaffold reveals induced-fit pocket plasticity of the BRD9 bromodomain. J. Med. Chem. 2015, 58: 2718-2736.

33. Hay DA, Rogers CM, Fedorov O, Tallant C, Martin S, Monteiro OP, Müller S, Knapp S, Schofield CJ, Brennan PE: Design and synthesis of potent and selective inhibitors of BRD7 and BRD9 bromodomains. MedChemComm. 2015, 6: 1381-1386.

34. Theodoulou NH, Bamborough P, Bannister AJ, Becher I, Bit RA, Che KH, Chung CW, Dittmann A, Drewes G, Drewry DH, Gordon L, Grandi P, Leveridge M, Lindon M, Michon AM, Molnar J, Robson SC, Tomkinson NCO, Kouzarides T, Prinjha RK, Humphreys, PG: Discovery of I-BRD9, a Selective Cell Active Chemical Probe for Bromodomain Containing Protein 9 Inhibition. J. Med. Chem. 2015, DOI: 10.1021/acs.jmedchem.5b00256.

35. Mirguet O, Lamotte Y, Donche F, Toum J, Gellibert F, Bouillot A, Gosmini R, Nguyen VL, Delannee D, Seal J, Blandel F, Boullay AB, Boursier E, Martin S, Brusq JM, Krysa G, Riou A, Tellier R, Costaz A, Huet P, Dudit Y, Trottet L, Kirilovsky J, Nicodeme E: From ApoA1 
upregulation to BET family bromodomain inhibition: Discovery of I-BET151. Bioorg. Med. Chem. Lett. 2012, 22: 2963-2967.

36. Clark PG, Vieira LC, Tallant C, Fedorov O, Singleton DC, Rogers CM, Monteiro OP, Bennett JM, Baronio R, Müller S, Daniels DL, Méndez J, Knapp S, Brennan PE, Dixon DJ: LP99: Discovery and Synthesis of the First Selective BRD7/9 Bromodomain Inhibitor. Angew Chem Int Ed Engl 2015, 54: 6217-6221.

37. Tough DF, Prinjha RK, Tak PP: Epigenetic mechanisms and drug discovery in rheumatology. Clinical Medicine 2015, 15: s64-s71.

38. Albrecht BK, Cote A, Crawford T, Benjamin F, Huang HR, Lora JM, Magnuson S, Nasveschuk CG, Salmeron A, Sims III RJ, Taylor AM: Treating Th2-mediated diseases by inhibition of bromodomains. WO2014144721A2.

39. Iyer NG, Özdag H, Caldas C: p300/CBP and cancer. Oncogene 2004, 23: 4225-4231.

40. Matt T: Transcriptional control of the inflammatory response: a role for the CREBbinding protein (CBP). Acta Medica Austriaca 2002, 29: 77-79.

41. Yao TP, Oh SP, Fuchs M, Zhou ND, Ch'ng LE, Newsome D, Bronson RT, Li E, Livingston DM, Eckner R: Gene dosage-dependent embryonic development and proliferation defects in mice lacking the transcriptional integrator p300. Cell 1998, 93: 361-372.

42. Sachchidanand, Resnick-Silverman L, Yan S, Mutjaba S, Liu WJ, Zeng L, Manfredi JJ, Zhou MM: Target structure-based discovery of small molecules that block human p53 and CREB binding protein association. Chem. Biol. 2006, 13: 81-90.

43. Borah JC, Mujtaba S, Karakikes I, Zeng L, Muller M, Patel J, Moshkina N, Morohashi K, Zhang W, Gerona-Navarro G, Hajjar RJ, Zhou MM: A small molecule binding to the coactivator CREB-binding protein blocks apoptosis in cardiomyocytes. Chem. Biol. 2011, 18: $531-541$.

44. Hewings DS, Wang M, Philpott M, Fedorov O, Uttarkar S, Filippakopoulos P, Picaud S, Vuppusetty C, Marsden B, Knapp S, Conway SJ, Heightman TD: 3,5-Dimethylisoxazoles act as acetyl-lysine-mimetic bromodomain ligands. J. Med. Chem. 2011, 54: 6761-6770.

45. Unzue A, Xu M, Dong J, Wiedmer L, Spiliopoulos D, Caflisch A, Nevado C: Fragmentbased design of selective nanomolar ligands of the CREBBP bromodomain. J. Med. Chem. 2015, DOI:10.1021/acs.jmedchem.5b00172.

46. Hay DA, Fedorov O, Martin S, Singleton DC, Tallant C, Wells C, Picaud S, Philpott M, Monteiro OP, Rogers CM, Conway SJ, Rooney TPC, Tumber A, Yapp C, Filippakopoulos P, Bunnage ME, Müller S, Knapp S, Schofield CJ, Brennan PE: Discovery and optimization 
of small-molecule ligands for the CBP/p300 bromodomains. J. Am. Chem. Soc. 2014, 136: 9308-9319.

47. Hammitzsch A, Tallant C, Fedorov O, O'Mahony A, Brennan PE, Hay DA, Martinez FO, Al-Mossawi MH, de Wit J, Vecellio M, Wells C, Wordsworth P, Müller S, Knapp S, Bowness P: CBP30, a selective CBP/p300 bromodomain inhibitor, suppresses human Th17 responses. PNAS 2015, 112: 10768-10773.

48. Piatnitski Chekler EL, Pellegrino JA, Lanz TA, Aldrin Denny R, Flick AC, Coe J, Langille J, Basak A, Liu S, Stock IA, Sahasrabudhe P, Bonin PD, Lee K, Pletcher MT, Jones LH: Transcriptional Profiling of a Selective CREB Binding Protein Bromodomain Inhibitor Highlights Therapeutic Opportunities. Chem. Biol. 2015, 22: 1588-1596.

49. Picaud S, Fedorov O, Thanasopoulou A, Leonards K, Jones K, Meier J, Olzscha H, Monteiro O, Martin S, Philpott M, Tumber A, Filippakopoulos P, Yapp C, Wells C, Hing Che K, Bannister A, Robson S, Kumar U, Parr N, Lee K, Lugo D, Jeffrey P, Taylor S, Vecellio ML, Bountra C, Brennan P, O'Mahony A, Velichko S, Muller S, Hay D, Daniels DL, Urh M, La Thangue NB, Kouzarides T, Prinjha R, Schwaller J, Knapp S: Generation of a selective small molecule inhibitor of the CBP/p300 bromodomain for leukemia therapy. Cancer Res. 2015, 75: 5106-541.

50. Albrecht BK, Audia JE, Bellon S, Andrea C, Cote A, Crawford T, Fauber B, Ghosh S, Harmanage JC, Hatzivassiliou G, Jayaram H, Kim J, Lora JM, Magnuson S, Mellman I, Romero FA, Taylor AM, Tsui V: Use of CBP/EP300 bromodomain inhibitors for cancer Immunotherapy. WP2015054642A2.

51. Medina PP, Carretero J, Fraga MF, Esteller M, Sidransky D, Sanchez-Cespedes M: Genetic and epigenetic screening for gene alterations of the chromatin-remodeling factor, SMARCA4/BRG1, in lung tumors. Gene Chromosome Canc. 2004, 41: 170-177.

52. Ortega SS, Balinas C, Cuadros M, Medina PP: SWI/SNF proteins as targets in cancer therapy. Journal of Hematology \& Oncology 2014, 7: 81-84.

53. Fedorov O, Castex J, Tallant C, Owen DR, Martin S, Aldeghi M, Monteiro O, Filippakopoulos P, Picaud S, Trzupek JD, Gerstenberger BS, Bountra C, Willmann D, Wells C, Philpott M, Rogers C, Biggin PC, Brennan PE, Bunnage ME, Schüle R, Günther T, Knapp $S$, Müller S: Selective targeting of the BRG/PB1 bromodomains impairs embryonic and trophoblast stem cell maintenance. Science Advances 2015, 1: e1500723.

- First disclosure of PFI-3, a chemical probe with a highly unusual binding mode that displaces four evolutionary conserved waters from the bromodomain binding pocket. PFI-3 and its negative control were used to demonstrate that inhibition of the SMARCA2/4 and PB1(5) bromodomains impairs embryonic and trophoblast stem cell maintenance. 
54. Vangamudi B, Paul TA, Shah PK, Kost-Alimova M, Nottebaum L, Shi X, Zhan Y, Leo E, Mahadeshwar HS, Protopopov A, Futreal A, Tieu TN, Peoples M, Heffernan TP, Marszalek JR, Toniatti C, Petrocchi A, Verhelle D, Owen DR, Draetta G, Jones P, Palmer WS, Sharma S, Andersen JN: The SMARCA2/4 ATPase Domain Surpasses the Bromodomain as a Drug Target in SWI/SNF-Mutant Cancers: Insights from cDNA Rescue and PFI-3 Inhibitor Studies. Cancer Res. 2015, 75: 3865-3878. 